УАK 347.91/.95

ББК 67.410 .1

DOI 10.22394/1682-2358-2019-5-38-44

A.A. Beletskaya, senior Lecturer of the Labor and Business Law Department, Institute of Law of Belgorod State National Research University

M.A. Sorokoletova, Senior Lecturer of the Labor and Business Law Department, Institute of Law of Belgorod State National Research University

\section{PROBLEM ASPECTS OF THE ARBITRATION REFORM: INNOVATIONS PROS AND CONS}

The results of the reform in the field of arbitration proceedings are studied. Opportunities for further improvement of legislation and law enforcement in the field of arbitration and arbitration court are analyzed.

Key words and word-combinations: arbitration court, arbitration, reform.
A.А. Белецкая, старший преподаватель кафедрь трудового и предпринимательского права торидического института Белгородского государственного начионального исследовательского yнuверситета (email: Beletskaya_A@bsu.edu.ru)

M.A. Сороколетова, стариий преподаватель кафедри трудового и предпринимательского права торидического института Белгородского государственного наиионального исследовательского университета (email:sorokoletova@bsu.edu.ru)

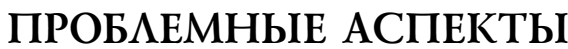 ТРЕТЕЙСКОЙ РЕФОРМЫ: ПАЮСЫ И МИНУСЫ НОВАЦИЙ}

Аннотащия. Исследуются результаты реформы в сфере третейского судопроизводства. Анализируется возможность дальнейшего совершенствования законодательства и правоприменения в сфере арбитража и третейского суда.

Ключевые слова и словосочетания: третейский суд, арбитраж, реформа.<smiles>C1CCCCC1</smiles>

1 сентября 2016 г. вступил в силу Федеральный закон от 29 Аекабря 2015 г. № 382-Ф3 «Об арбитраже (третейском разбирательстве) в Российской Федерации» [1], а также Фелерахьный закон № 409-Ф3 «О внесении изменений в отдельные законодательные акты Российской Федерации и признании утратившим силу пункта 3 части 1 статьи 6 Федерального закона “О саморегулируемых организациях” в связи 
с принятием Федерального закона "Об арбитраже (третейском разбирательстве) в Российской Федерации”» [2] .

В настояшее время в юридической митературе основательно излагаются результаты недавней масштабной модернизации законодательства об арбитраже [3, с. 14]. Рассматривается обширный перечень преобразований, коснувшихся практически всех сфер арбитражка. Во многих работах описываются значительные изменения в законодательстве и правоприменительной практике третейского разбирательства.

Арбитражи играют особую роль в развитии частноправовой сферы. Отношения предпринимателей, связанные с формированием третейского суда и передачей спора на его рассмотрение, основаны исключительно на частных интересах. Разбирательство дел в третейских судах и коммерческих арбитражах - это особая форма частного воздействия на общественные отношения. При этом межАународный коммерческий арбитраж и третейское разбирательство остаются распространенными формами правоприменения и явмяются важными элементами системы гражАанской юрисдикции.

Возникает вопрос, насколько основательно новый закон о третейском разбирательстве защищает интересы участников гражданских правоотношений, с какими проблемами сталкиваются стороны третейских споров и дают $\Lambda и$ изменения обновленного законодательства возможность устранить эти проблемы.

В юридической среде распространено мнение, что ни один закон не может в равной степени удовметворять всех - у каждого существует особый взгляА. Именно поэтому в данном исследовании рассматриваются разные точки зрения на первые результаты «третейской» реформы. Это может дать возможность более широко обозначить диапазон тенденций дальнейшего совершенствования законодательства и правоприменения в сфере арбитража и третейского суда, поскольку, на наш взгляА, такое совершенствование должно продолжаться.

Законодателями на стадии подготовки законопроектов продекларированы главные цели реформы: устранить змоупотребления, допускаемые третейскими судами; создать более благоприятные условия дия развития внутреннего третейского разбирательства; повысить востребованность института коммерческого арбитража и снизить рабочую загрузку государственных национальных судов; сделать Россию более привлекательным местом для международного арбитража. Как подчеркивает председатель правления Арбитражной ассоциации В.В. Хвалей, изменения настолько существенны, что затрагивают интересы практически всех Аиц, тем или иным образом участвующих в третейском разбирательстве [4, с. 87].

Обратимся к наиболее, как представмяется, значимым нововведениям, касающимся отдельных внутригосударственных аспектов. Проанализируем одно из кмючевых и широко обсуждаемых нововведений рассматриваемого Закона - порядок создания третейских судов (гл. 9). Изменения коснулись порядка формирования постоянно действующих арбитражных учреждений (ПААУ) - закреплен разрешительный порядок создания. 
Правительство РФ предполагает выдавать разрешения некоммерческой организации на осуществление функций постоянного действующего арбитражного учреждения. Совет по совершенствованию третейского разбирательства будет задействован как орган, подготавливающий рекомендации на выдачу разрешений. Следовательно, институциональные арбитражи могут создаваться только при некоммерческих организациях, а рекомендации готовятся по итогам анализа исполнения соответствующих требований, предусмотренных Федеральным законом № 382 .

Помимо увеличения количества третейских судов, наблюдалось несоблюдение предусмотренной процедуры разрешения споров, нередко игнорировались основополагающие принџипы равенства и беспристрастности. Арбитражи обслуживали конкретные бизнес-интересы, отнюдь не решая задачу обеспечения достойной альтернативы государственным судам. Исследователи утвержАают, что из почти пятисот третейских учреждений московского региона многие были образованы крупнейшими российскими компаниями и банками [5, с. 20]. Следовательно, официально задача указанных нововведений может трактоваться как борьба с «карманными» третейскими судами, существование которых сказывается на имидже всей системы, а также со «скороварками», ставящими «на поток производство решений третейских суАов, и «решалами» - в основном «профессиональными жуликами от юриспруденции» [6, с. 48$]$.

Многие специалисты, работающие в сфере арбитража, считают эту меру, то есть установление разрешительного порядка создания в Российской Федерации постоянно действующих арбитражных учреждений, резонной и, что важно, удавшейся. В частности, А.Горленко, генеральный директор АНО «Институт современного арбитража», в интервью корреспонденту газеты «Коммерсант» отметил: «Если говорить о том, удаАось $и$ Аостичь џели в части борьбы с разАичного рода зАоупотреблениями со стороны постоянно действующих третейских судов, которые вводили в заблуждение участников оборота (маскируясь поА государственные суды с гербами, удостоверениями и мантиями), занимались полулегальными или криминальными делами, то да, удалось. Несмотря на отдемьные проявления “изобретательности” со стороны таких представителей “третейского бизнес-сообщества” с целью сохранить свой “бизнес” после 1 ноября, мы уже видим: большая часть таких учреждений разрешения не получима» [7] .

Несмотря на это, ряд экспертов считают, что предлагаемый порядок образования третейских судов не сможет реализовать существующие задачи. «Аیя организаций, которые имеют при себе “карманные” третейские суды, - считают в Ассоџиаџии участников по содействию в развитии третейского разбирательства, - не вызовет сложности созАание некоммерческой организации и при ней третейского суда. Таким же путем несложно будет сформировать органы управления такого третейского суда из киџ, по сути связанных с ней, но формально не являющихся представитемями такой компании» [8, с. 143] .

Противники разрешительной проџеАуры создания третейских судов, поАчеркивают, что она предусматривает определенную зависимость процесса их создания и функционирования от волеизъявления органов государственной 
власти. Они настаивают на укреплении диспозитивных, Аоговорных начал правового регулирования в Аанной сфере [9]. Более того, заявияется категоричная точка зрения, что именно «огосударствление» становится кАючевой идеей реализации указанного Закона № 382 [10, с. 54] .

Их оппоненты убеждены, что отсутствие государственного контроля привело к Аискредитации института третейских судов и его неспособности эффективно применяться Аля решения многих вопросов бизнеса, как это делается во всем мире. Усиление государственного влияния на проџесс создания третейских суАов позволит избежкать недостатков в функционировании третейских судов.

Рассматривая правовой статус иностранного арбитражного учреждения и его возможность быть участником третейских правоотношений на территории России, следует учесть, что Аля реализации своих компетенций ему необхоАимо заручиться соответствующим разрешением Правительства РФ. Решения арбитров, принятые на территории Российской Федерации при администрировании иностранными арбитражками, которые не имеют соответствующего разрешения Правитеиьства РФ, в России будут рассматриваться в качестве решений третейских судов ad hос, то есть суда, осуществляющего арбитражк при отсутствии аАминистрирования со стороны постоянно действующего арбитражного учреждения (п. 3 ст. 44; п. 17 ст. 2).

Аیя получения разрешения на осушествление функций арбитражного учрежкдения российской некоммерческой организацией Аолжны быть выполнены несколько требований, в числе которых - обладание соответствующей высокой репутацией, тогда как Аля иностранных арбитражных учреждений требуется только международная репутация, получившая широкое признание. Нацичие таких репутационных требований может вызвать определенную опасность субъективного усмотрения при оџенке их соблюдения и привести к спорным ситуациям вследствие возможных необоснованных отказов в выдаче разрешений на осуществление деятельности.

Подчеркнем, что Аля обеспечения полноџенной и эффективной работы института третейских судов правовое регулирование проводится в рамках размичных отраслей законодательства. Наряду с Законом об арбитраже принят Закон № 409-Ф3, внесший изменения и Аополнения в различные законодательные акты, в том числе в Законы РФ от 7 июля 1993 г. № 5338-1 «О межаународном коммерческом арбитраже» [11] , от 7 июмя 1993 г. № 5340-1 «О торгово-промышленных палатах в Российской Федерации» [12], АПК РФ [13], ГПК РФ [14]. Изменения и Аополнения, внесенные в АПК РФ и ГПК РФ, определяют общий подход в отношении арбитрабельных и неарбитрабельных споров, то есть тех, которые могут быть переданы дия разрешения третейского суда и тех, которые не могут быть переданы дия разрешения третейского суда.

Весьма актуальной представляется проблема уточнения круга арбитрабельных споров с определением того, какие именно категории споров могут передаваться на рассмотрение в арбитраж. Невозможность объекта спора быть предметом арбитражного разбирательства явцяется одним из оснований Аля отмены арбитражного решения ици отказа в исполнении такого решения, 
применяемых по инициативе суда. Примером тому может служить сложившаяся неоднозначная практика российских судов в Аанном вопросе.

Важной новемлой явцяется то, что теперь в новом законодательстве более четко прописано взаимодействие третейских и государственных судов, в том числе обязанность государственных судов содействовать арбитрам, Аействующим по регламентам ПААУ, в получении доказательств. Существенным явмяется Аополнение детальным регулированием порядка выполнения государственными судами запросов третейского суда или стороны спора с согласия третейского суда об оказании содействия в получении необходимых в проџессе доказательств. Нормы, регулирующие вопросы исполнения таких запросов, Аобавлены в кодексы. Так, в АПК РФ Аобавлена статья 74.1, в соответствии с которой запрос третейского суда подлежит рассмотрению и исполнению (ици отказу в исполнении) в течение тридцати Аней со Аня его получения судом. Содействие получению доказательств, несмотря на то что нормы об этом расположены в главах о доказательствах, следует отнести к еще одной форме оказания содействия третейским судам. Из этой проџедуры исключены арбитражи дяя разрешения конкретного спора.

ОАнако реформа третейского законодательства, по мнению некоторых исследователей, не решила проблему улучшения качества судебного контроля наА решениями третейских судов. Так, при подготовке законопроекта Российская арбитражная ассоџиаџия предлагала вынести вопросы, связанные с судебным контролем наА третейским разбирательством, на уровень апемляџии мибо кассаџии, как это предусмотрено, а по вопросам международного арбитража перенести все подобные дела в Москву, но данное предложкение осталось нереализованным.

Еще не решены и вопросы, связанные с проблемой резкого сокращения числа третейских судов и связанных с этим последствий, а также с проблемой Аоступности третейских судов Аля преАпринимателей. В связи с масштабными изменениями в третейском разбирательстве резко возрастает количество обращений сторон в арбитражные суды, что значительно увеличивает нагрузку и не кучшим образом сказывается на их функционировании. Вопрос о повышении доступности при сокращении общего количества третейских судов остается очень актуальным, и ответа на него законодатель пока не дает [15, с. 6] .

Особо следует выделить проблему правового обеспечения механизма исполнения решений третейских судов. Существенными преАставцяются законодательные положения, а также выработанные судебной практикой подходы к вопросам об исполнимости решений третейских судов.

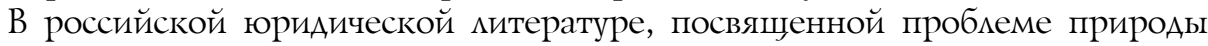
института третейского суда, встречаются Ава взаимоискиючающих мнения. ОАни ученые-правовеАы считают третейский суА органом правосудия, Аругие отрицают данную точку зрения.

По мнению Е.А. Суханова, третейский суд явцяется органом судебной защиты гражАанских прав, подобно государственному арбитражному суду и государственному суду общей юрисдикции. Аействуя в этом качестве, третейский суд не оказывает сторонам «юридическую услугу» и тем более не осуществляет предпринимательскую деятельность, а осуществляет правосудие. 
При этом отсутствие законодательного упоминания о третейских судах в нормативных правовых актах о судоустройстве объясняется именно тем, что они не включены в иерархию государственных судов и поэтому не входят в судебную систему [16, с. 118] . С подобным статусом можно связать своего рода «многоступенчатосты в приведении в исполнение решения третейских судов.

По обшему правилу стороны исполняют решение третейского суда добровольно. В противном случае они могут воспользоваться мерами государственного принуждения, а именно, обратиться в арбитражный суд с заявлением о выдаче исполнительного миста на принудительное исполнение решения третейского суда. Заявление подается в арбиттражный суд субъекта РФ по месту нахождения или месту жительства Аолжника, а если сведения об этом отсутствуют - по месту нахождения имушества должника. После вступления в силу привнесенных реформой законодательных изменений у сторон третейского разбирательства появилась возможность заключить соглашение о подаче заявмения в суА по месту нахождения третейского суда или по месту нахождения взыскатемя (ч. 3 ст. 236 АПК РФ). Они имеют право обратиться с заявлением о выдаче исполнительного листа на принудительное исполнение решения третейского суда, к которому при его кегализации государственным судом возможно в дальнейшем применение судебных мер стимулирования исполнения (то есть компенсаџии за неисполнение), которые аналогичны мерам, применяемым в отношении решений государственных судов.

Итак, третейская реформа преследовала следующие основные цели: повышение авторитета третейских судов; усиление востребованности указанного института гражданского общества; повышение качества разбирательства Аел третейскими судами; устранение змоупотреблений в сфере создания третейских судов; приведение в соответствие с нормами международного коммерческого арбитража действующего российского законодательства; уменьшение загруженности государственных судебных органов.

Результатом крупномасштабной реформы в области третейского разбирательства явицось не только внесение изменений в действующее законодательство, отвечающих современным требованиям диспозитивного института гражданского общества. Можно считать, что принято качественно новое законодательство, иначе выстраивающее правовое регулирование третейского разбирательства, хотя отнюдь не во всем увязанное с правовой природой разрешения споров третейскими судами.

Современное правовое регулирование института содействия третейским судам обладает не сопрягающимися с третейским разбирательством чертами заформализованности, чрезмерной императивности и огосударствления. Механизмы повышенного контроля, осуществляемого государственными судами, практически ставят в подчинение данный институт гражданского общества государственным судам российской судебной системы, в которую они по-прежнему не входят, что по меньшей мере нелогично.

Согласимся с мнением ряда специалистов о том, что укрепление оправдавшихся на практике нововведений в арбитражное законодательство и развитие арбитража в России в цемом займет не менее 5-10 мет. Многие юрисдикции 
в Европе и Азии уже приобрели опыт развития и попумяризации арбитража, и их «рецепты» надмежит изучать, анализировать и, по возможности, эффективно применять с учетом российских реалий. Попытки прямого заимствования и слепого копирования зарубежных правовых институтов и конструкщий не могут стать эффективным способом развития национального законодательства.

В рамках отдельной статьи сложно охватить весь спектр проблем, возникающих в связи с реформированием системы российского третейского разбирательства. Именно поэтому рассматриваются мишь некоторые вопросы, которые, на наш взглял, могут иметь наибольшее значение Аля системы амьтернативного разрешения споров.

\section{Библиографический список}

1. Об арбитраже (третейском разбирательстве) в Российской Федерации: Федер. закон от 29 дек. 2015 г. № 382-Ф3 // С3 РФ. 2016. № 1 (ч. І). Ст. 2.

2. О внесении изменений в отдельные законодательные акты Российской Федерации и признании утратившим силу пункта 3 части 1 статьи 6 Федерального закона "О саморегулируемых организациях" в связи с принятием Федерального закона "Об арбитраже (третейском разбирательстве) в Российской Федерации”: Федер. закон от 29 дек. 2015 г. № 409-Ф3 (в ред. от 3 июля 2016 г.) // СЗ РФ. 2016. № 1 (ч. І). Ст. 29.

3. Курочкин C.A. Третейское разбирательство и международный коммерческий арбитраж. M., 2017.

4. Хвалей В.В. Новое законодательство об арбитраже: жить стало лучше, жить стало веселее // Закон. 2016. № 5. С. 87-95.

5. Городисский А.А., Тобар Кириллов Хосе Константино. Обзор третейской реформы / Комментарий законодательства. 2016. № 1.

6. Научно-практический постатейный комментарий к законодательству о третейских судах / под общ. ред. В.В. Хвалея. М., 2017.

7. Занина A., Горленко $A$. Не могу сказать, что к нам как-то лучше и легче относились. URL: https://www.kommersant.ru/doc/3454661?from=doc_vrez

8. Жилина М. 1 сентября - в третейский суд по новым правилам // Информационно-аналитический журнал «Арбитражные споры». 2016. № 3. С. 143-154.

9. Колесникова Е.A. Институт содействия третейским судам: новая проблема или решение. URL: https://legalscience.ru/images/PDF/2017/19/institut-sodejstviya.pdf

10. Терехова Л.А. Выполнение судами функций содействия в отношении третейских судов // Вестник гражданского процесса. 2016. № 6. С. 54-62.

11. О международном коммерческом арбитраже: Закон РФ от 7 июля 1993 г. № 5338-1 // Ведомости СНД и ВС РФ. 1993. № 32. Ст. 1240.

12. О торгово-промышленных палатах в Российской Федерации: Закон РФ от 7 июля 1993 г. № 5340-1 // Ведомости СНД и ВС РФ. 1993. № 33. Ст. 1309.

13. Арбитражный процессуальный кодекс Российской Федерации от 24 июля 2002 г. № 95-Ф3 // С3 РФ. 2002. № 30. Ст. 3012.

14. Гражданский процессуальный кодекс Российской Федерации от 14 ноября 2002 г. № 138-Ф3 // С3 РФ. 2002. № 46. Ст. 4532.

15. Дымова Ю. Как реформа отразится на правоприменительной практике // ЭЖ-Юрист. 2017. № 46.

16. Савина О.А. Институт третейского разбирательства как инструмент защиты нарушенных или оспоренных гражданских прав: история становления и правовая природа // Современное право. 2015. № 9. С. 118-122. 